\title{
Modeling and Design of a Prototype Footstep Power Generating Machine
}

\author{
Israel Enema Ohiemi ${ }^{1}$, Nnorum Choice Obundah ${ }^{1}$, Ugwuoke Cornelius Chinoso ${ }^{1}$, Israel Ojo Enock ${ }^{2, *}$, \\ Kolo Yetu Babazhitsu ${ }^{2}$, Ayuba Elkanah Jatau ${ }^{3}$, Elvis Adam Alhassan ${ }^{4}$ \\ ${ }^{1}$ Department of Mechanical Engineering, University of Nigeria, Nsukka, Nigeria. \\ ${ }^{2}$ Department of Mechanical Engineering, Federal Polytechnic Bida, Bida, Niger State, Nigeria. \\ ${ }^{3}$ Department of Mechanical Engineering, Technology, Niger State Polytechnic, Zungeru, Niger State, Nigeria. \\ ${ }^{4}$ Faculty of Mathematical Sciences, C.K. Tedam University of Technology and Applied Sciences, Navrongo, Upper East Region, \\ Ghana.
}

How to cite this paper: Israel Enema Ohiemi, Nnorum Choice Obundah, Ugwuoke Cornelius Chinoso, Israel Ojo Enock, Kolo Yetu Babazhitsu, Ayuba Elkanah Jatau, Elvis Adam Alhassan. (2021) Modeling and Design of a Prototype Footstep Power Generating Machine. Engineering Advances, 1(2), 67-82. DOI: $10.26855 /$ ea.2021.12.005

Received: November 15, 2021

Accepted: December 10, 2021

Published: December 30, 2021

*Corresponding author: Israel Ojo Enock, Department of Mechanical Engineering, Federal Polytechnic Bida, Bida, Niger State, Nigeria.

Email: enockoi@abuad.edu.ng

\begin{abstract}
This paper presents a non-conventional method of electrical power generation through the design, modelling and fabrication of a footstep power generating system. It is configured to generate electricity as long as there is a foot force on it. The system consists mainly of a connecting rod, gears, u-shaped shaft, and an alternator. The component members were designed, while static and fatigue analyses were carried out using Autodesk Inventor software. The static and fatigue analysis of both spring and footboard revealed yield strength of $207 \mathrm{Gpa}$ and a factor of safety of 12 for spring and 6.58 for footboard. Basic manufacturing processes were employed during the construction of the machine. The results show an output power of $0.912 \mathrm{~W}$, voltage of $1.52 \mathrm{~V}$, and an efficiency of $21 \%$ when an average mass of $62 \mathrm{~kg}$ acted on it. The root mean square value greater than 0.9 shows a strong correlation of the predictive model.
\end{abstract}

\section{Keywords}

Power Generation, Footstep, Autodesk, Electrical Energy

\section{Introduction}

Electricity is the most convenient and versatile form of energy and in high demand, it is growing at a faster rate than other forms of energy and plays a crucial role in the industrial and agricultural sectors [1]. Electricity is most often generated at a power station by electromechanical systems, primarily driven by heat engines fueled by combustion or nuclear fission but also by other means such as the kinetic energy of flowing water and wind. Other energy sources include solar photovoltaic and geothermal power [2].

The fundamental principles of electricity generation were discovered in the 1820s and early 1830s by British scientist Michael Faraday [3]. His method is still in use today. Electricity can be generated by the movement of a loop of wire, or disc of copper between the poles of a magnet [4].

The consumption of electricity is an index of the productivity and growth of a country. Therefore, power development has been given high priority in development programs [5]. The increase of the human population in the country has necessitated and multiplied the need for use of energy to do work and to improve well-being than ever existed millions of years ago. As a result, many resources are being wasted with attendant consequences on health and the environment [6]. So, non-conventional energy is very essential at this time to any nation. Walking is a common activity performed by people daily. There is a loss in kinetic energy due to the weight transfer to the surface of the foot during walking. Therefore, the energy of the person from the footstep can be converted to electrical energy. Human power is an attractive energy source. Footstep power generating system is a nonconventional/renewable source of energy that reduces environmental pollution (such as air pollution caused by burning of fossil fuels and improves public health) 
thereby reducing premature mortalities due to pollution and saving associated health costs [7].

\section{Design Analysis and Calculations}

\subsection{Spring Design}

The average mass $(\mathrm{m})$ of humans is $m=62 \mathrm{~kg}$ [8].

From the century spring corporation (CSC) catalog standard for steel with a modulus of rigidity (G) of 80GPa, the outer diameter (OD) is $36 \mathrm{~mm}$. similarly; the inner diameter (ID) is $30 \mathrm{~mm}$

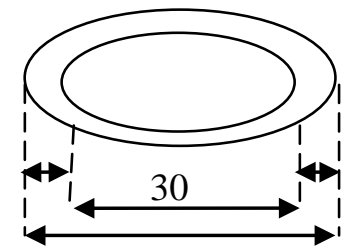

36

Figure 1. Spring Cross Section.

The spring wire diameter (d) in Figure 1 can be calculated using the formula

$$
\begin{gathered}
O . D=I . D+2 d \\
36=2 d+30 \\
\rightarrow d=\frac{36-30}{2}=3 \mathrm{~mm} \\
d=3 \mathrm{~mm}
\end{gathered}
$$

Force $(\mathrm{F})=$ mass $(\mathrm{m}) \times$ acceleration due to gravity $(\mathrm{g})$

$$
F=m g
$$

$$
F=62 \times 9.81=608.22 N
$$

Four springs are to be used in this design, so the average force that'll act on each spring is given as:

$$
\text { Average Load }=\frac{608.22}{4}=152.055 \mathrm{~N}
$$

Let the deflection resulting from the average load of $152.055 \mathrm{~N}$ be $90 \mathrm{~mm}$

$$
\begin{gathered}
K=\frac{F}{\delta} \\
K=\frac{152.055}{90}=1.7 \mathrm{~N} / \mathrm{mm}
\end{gathered}
$$

where

$$
K=\text { spring rate }, F=\text { load } \delta=\text { deflection }
$$

Number of coils $(\mathrm{N})$ required for the spring is calculated thus:

$$
K=\frac{G d^{4}}{8 \times D^{3} \times N} \rightarrow N=\frac{G d^{4}}{8 K D^{3}}
$$

[9]

Where, mean diameter $(D)=$ O.D $-\mathrm{d}=33 \mathrm{~mm}$

$\mathrm{O} . \mathrm{D}=$ outer diameter and $\mathrm{d}=$ wire diameter

$$
\text { Hence, } N=\frac{80 \times 10^{3} \times 3^{4}}{8 \times 1.7 \times 33^{3}}=13.6
$$

$\therefore \quad$ Number of turns of the spring $(\mathrm{N})=14$

The torque (T) acting on the springs is given as:

$$
T=F \times D / 2
$$


[9]

$$
\begin{gathered}
T=608.22 \times 18 \\
T=10947.96 \mathrm{~N}-\mathrm{mm}
\end{gathered}
$$

The shear stress in the spring is given thus:

[9]

$$
\frac{T}{J}=\frac{\tau}{r}
$$

$$
\rightarrow \tau=\frac{T r}{J}
$$

where

$J$ is polar moment of inertia of spring wire

$$
\begin{gathered}
J=\frac{\pi d^{4}}{32}=7.95 \\
r=D / 2=18
\end{gathered}
$$

$r$ is the radius of wire diameter

$$
\tau=\frac{10947.96 \times 18}{7.95}=24787.83 \mathrm{~N} / \mathrm{mm}^{2}
$$

\subsection{Bearing Design}

From the gear specifications, its approximate weight $=25.9 \mathrm{~N}$ and the weight of the connecting rod $=5 \mathrm{~N}$. These weights constitute

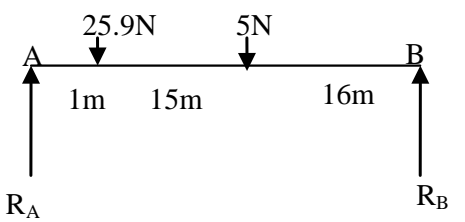

Figure 2. Force Diagram.

the forces acting on the shaft on the bearing illustrated in Figure 2 .

$$
\begin{aligned}
& \sum_{\uparrow} \uparrow R_{A}+R_{B}-25.9-5 \\
& \rightarrow R_{A}+R_{B}=30.9
\end{aligned}
$$

Where $R_{A}$ and $R_{B}$ are reactions at points $\mathrm{A}$ and $\mathrm{B}$, respectively.

The moment about point $\mathrm{A}$ is given by:

$$
\begin{gathered}
\sum M_{A}=0 \\
R_{B} \times 32=25.9 \times 1+5 \times 16 \\
R_{B}=\frac{25.9+80}{32}=3.31
\end{gathered}
$$

Substitute $R_{B}=3.31$ into equation (1)

$$
R_{A}=30.9-R_{B}=27.59 \mathrm{~N}
$$

Since $R_{A}$ and $R_{B}$ are 27.59 and 3.31 respectively. The bearing loads are small; therefore, the recommended bearing is a journal bearing. Table 1 shows the bearing specification.

Table 1. Specification of Ball Bearing R1804

\begin{tabular}{cc}
\hline Description & Value \\
\hline Bore(d) & $26 \mathrm{~mm}$ \\
Outer Diameter (OD) & $42 \mathrm{~mm}$ \\
Width (B) & $7 \mathrm{~mm}$ \\
\hline
\end{tabular}




\begin{tabular}{cc}
\hline Ball No. & 14 \\
Ball Size & $3.3 \mathrm{~mm}$ \\
Dynamic Load Rating (C) & 750 \\
Static Load Rating $\left(\mathrm{C}_{0}\right)$ & 480 \\
\hline
\end{tabular}

$$
\text { Angle of Contact } C_{0}=f_{0} i Z D^{2} \cos \alpha
$$

[10]

Where;

$\mathrm{i}=$ Number of rows of balls in any one bearing $=1$

$\mathrm{Z}=$ Number of ball per row $=14$

$\mathrm{D}=$ Diameter of balls $=3.3 \mathrm{~mm}$

$\alpha=$ Angle of contact

$f_{o}=$ A factor depending upon the type of bearing $=3.33$ for ball bearing

$$
\begin{gathered}
\cos \alpha=\frac{C_{0}}{f_{0} \times i \times z \times D^{2}} \\
\cos \alpha=\frac{480}{3.33 \times 1 \times 14 \times 3.3^{2}} \\
\alpha=19.56^{\circ}
\end{gathered}
$$

The life of the bearing is given by the formula below

$$
L_{1}=\left(\frac{C}{W_{1}}\right)^{3} \times 10^{6} \text { revolutions }
$$

[9]

where,

$\mathrm{L}=$ bearing life

$\mathrm{C}=$ dynamic load rating $=750$

$\mathrm{W}=$ dynamic load

$\mathrm{k}=3$ for ball bearing.

For Section A:

$\mathrm{W}=\mathrm{R}_{\mathrm{A}}=27.59 \mathrm{~N}$

[9]

$$
L=\left(\frac{C}{W}\right)^{3} \times 10^{6} \text { revolutions }=\left(\frac{750}{27.59}\right)^{3} \times 10^{6} \text { revolutions }=2.0 \times 10^{10} \text { revolutions }
$$

For Section B:

$$
\begin{gathered}
W=R_{B}=3.31 \\
L=\left(\frac{C}{W}\right)^{K} \times 10^{6} \text { revolutions } \\
L=\left(\frac{750}{3.31}\right)^{3} \times 10^{6} \text { revolutions } \\
=1.16 \times 10^{13} \text { revolutions }
\end{gathered}
$$

The resulting calculation above shows that the bearing chosen is suitable for the project as it has many revolutions to undergo before failure and the bearings used are journal bearings because it is readily available.

\subsection{Shaft Design}

The specifications of the shaft below were assumed with respect to its availability and the resulting deflection calculated

Let the length of the shaft $(\mathrm{L})$ be $320 \mathrm{~mm}$

Diameter of the shaft $=24 \mathrm{~mm}$

Selected shaft material is steel.

Modulus of Rigidity of steel (G) = 80 GPa 
The deflection that the shaft will experience is given by the equation below

$$
\delta=\frac{F L^{3}}{3 G I}
$$

[10]

where;

$\mathrm{F}=\mathrm{W}=$ shaft load

$$
\begin{gathered}
\text { Moment of Inertia I }=\frac{\pi d^{4}}{64}=\frac{\pi \times 24^{4}}{64}=16286.02 \\
\therefore \delta=\frac{30.9 \times 320^{3}}{3 \times 80 \times 10^{3} \times 16286.02}=0.259 \mathrm{~mm}
\end{gathered}
$$

This means that the material of the shaft is suitable for the project because its deflection as a result of the weight is within limit.

The torque $\mathrm{T}$ acting on the shaft is given by the equation

$$
T=F \times d / 2
$$

[10]

Where the force $\mathrm{F}$ on the shaft is 30.9

$$
=30.9 \times 12=370 \mathrm{Nmm}
$$

The shear stress is calculated using the formula:

$$
\frac{T}{J}=\frac{\tau}{r}
$$

[9]

$$
\rightarrow \tau=\frac{T r}{J}
$$

Where,

$$
J=\frac{\pi d^{4}}{32}=32572.03
$$

Hence,

$$
\tau=\frac{370.8 \times 24 / 2}{32572.03}=0.1366 \mathrm{~N} / \mathrm{mm}^{2}
$$

To determine depth value of the shaft " $\mathrm{h}$ ". The maximum compression allowable on the spring is $120 \mathrm{~mm}$. So, let the maximum vertical deflection of the spring be $X=120 \mathrm{~mm}$. When rotated, the u-shaped shaft creates a virtual circle.

NOTE: The depth of shaft was determined with respect to the extent of compression of the spring, this is in order to enable the shaft make full revolutions.

Now, let points A and B be just a little more than $180^{\circ}$ say $185^{\circ}$ apart. The angular distance S (length of arc subtended by $185^{\circ}$ of the circle) between these points should be less than or equal to the maximum spring deflection.

Hence, calculating for $h=r$

$$
\begin{gathered}
X=S=120 \mathrm{~mm} \\
\theta=185^{\circ} \text { and } S=\text { length of arc } \\
\therefore S=\frac{\theta}{360} \times 2 \pi r \\
\rightarrow r=\frac{360 \times S}{2 \pi \theta}=\frac{360 \times 120}{2 \times \pi \times 180}=37.165 \mathrm{~mm}
\end{gathered}
$$

Therefore,

$$
h=r=37.165 \mathrm{~mm}
$$

It is important to note that the vertical deflection of the spring is tactically calculated to make the shaft rotate to approximately $185^{\circ}$, the spring compression stops here and the completion of the shaft rotation is achieved by the spring 
return, thereby completing a revolution of $360^{\circ}$.

\subsection{Gear Design}

The aim is to get a gear ratio of $4: 1$, the specifications of gears were chosen due to its availability

For the driving gear,

Number of teeth $=36$

Pitch circle diameter $=106 \mathrm{~mm}$

Inner diameter $=24 \mathrm{~mm}$

For the driven gear,

Number of teeth $=9$

Pitch circle diameter $=24 \mathrm{~mm}$

Inner diameter $=10 \mathrm{~mm}$

$$
\text { Circular Pitch }\left(P_{c}\right)=\pi D / T
$$

Where,

$\mathrm{D}=$ Diameter of the pitch circle $=106 \mathrm{~mm}$

$\mathrm{T}=$ Number of teeth on the wheel $=36$

$$
\begin{gathered}
\therefore P_{c}=\frac{\pi \times 106}{36}=9.25 \mathrm{~mm} \\
\text { Diametral Pitch }\left(P_{d}\right)=\frac{T}{D} \\
\therefore P_{d}=\frac{36}{106}=0.34 \text { teeth } / \mathrm{mm} \\
\operatorname{Module}(M)=\frac{D}{T} \\
\therefore M=\frac{106}{36}=3 \mathrm{~mm}
\end{gathered}
$$

Table 2 shows the standard proportion for gear systems of $20^{\circ}$ full depth involute.

Table 2. Standard Proportion for Gear Systems of 20o Full Depth Involute

\begin{tabular}{ccc}
\hline $\boldsymbol{S} / \boldsymbol{n}$ & Particulars & $\mathbf{2 0}^{\mathbf{o}}$ full depth involute system \\
\hline $\mathbf{1}$ & Addendum & $1 \times 3=3 \mathrm{~mm}$ \\
$\mathbf{2}$ & Dedendum & $1.25 \times 3=3.75 \mathrm{~mm}$ \\
$\mathbf{3}$ & Working depth & $2 \times 3=6 \mathrm{~mm}$ \\
$\mathbf{4}$ & Minimum total depth & $2.25 \times 3=6.75 \mathrm{~mm}$ \\
$\mathbf{5}$ & Tooth thickness & $1.5708 \times 3=4.71 \mathrm{~mm}$ \\
$\mathbf{6}$ & Minimum clearance & $0.25 \times 3=0.75 \mathrm{~mm}$ \\
$\mathbf{7}$ & Fillet radius at root & $0.4 \times 3=1.2 \mathrm{~mm}$ \\
\hline
\end{tabular}

$$
\operatorname{Velocity} \text { ratio }(V R)=\frac{T_{1}}{T_{2}}
$$

where $T_{1}=$ Number of teeth of small gear $=9$

$T_{2}=$ Number of teeth of big gear $=36$

$$
V R=\frac{9}{36}=0.25
$$

Check for interference

$$
T_{1} \geq \frac{2 a w \frac{1}{T_{2}} P_{d}}{\sqrt{1+\frac{1}{T_{2}}\left(\frac{1}{T_{2}}+2\right) \sin ^{2} \varphi-1}}
$$


where

$T_{1}=$ the number of teeth of the small gear

$$
\begin{gathered}
P_{d}=0.34 \text { teeth } / \mathrm{mm} \\
a w=M=\text { Module }=3 \mathrm{~mm} \\
\varphi=20^{\circ} \\
T_{1} \geq \frac{2 \times 3 \times \frac{1}{36} \times 0.34}{\sqrt{1+\frac{1}{36}\left(\frac{1}{36}+2\right) \sin ^{2} 20-1}} \\
T_{1} \geq 0.7
\end{gathered}
$$

This means that there is no interference.

\section{Fabrication and Testing}

The 3-D drawing and constructed figure of the footstep power generating machine is shown in Figure 3 (a) and Figure 3 (b)

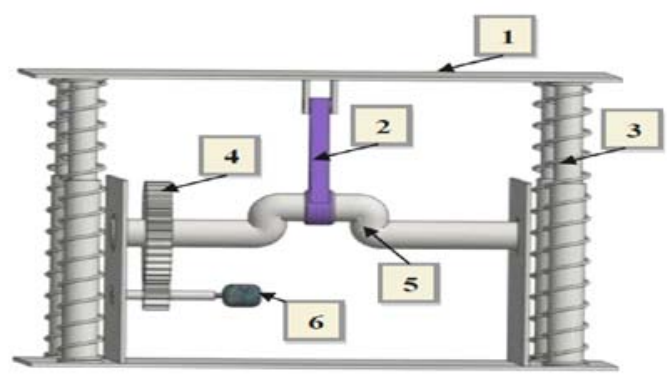

1. Footboard

2. Connecting rod

3. Spring

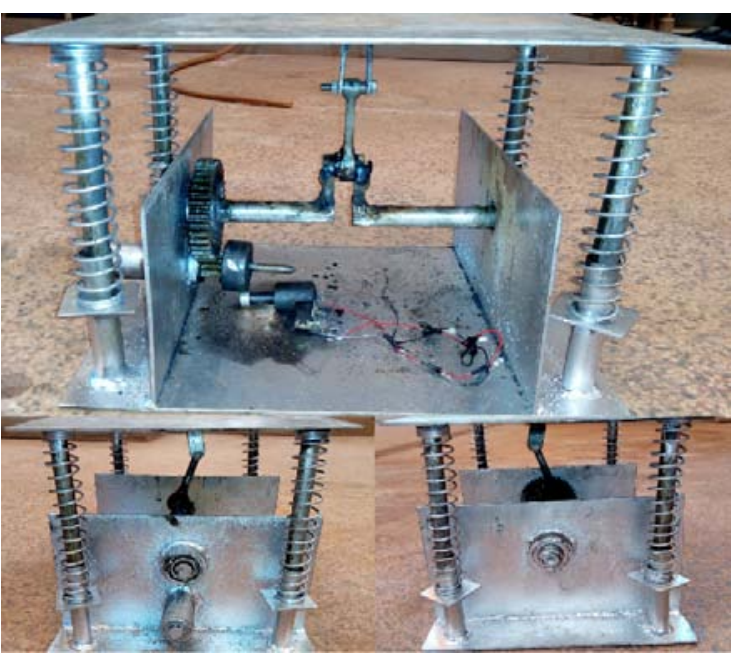

(b)

(a)

Figure 3. Footstep Power Generating Machine (a) 3D model (b) Fabricated.

The design of the footstep power generating machine includes essential components such as: The foot board where the force is applied, helical compression spring to return the system to its original position when the load is removed, shaft to transmit power to the gear. Connecting rod to convert reciprocating motion into rotational motion. Other equipment includes: gears, bearing, D.C. generator, multimeter and light emitting diode (LED) bulbs. The selected materials are discussed in Table 3.

Table 3. Materials Listing and Specifications

\begin{tabular}{ccc}
\hline Name of component & Specification $(\mathbf{m m})$ & Material used \\
\hline Plate & $400 \times 300 \times 4$ & Mild Steel \\
Base & $400 \times 300 \times 4$ & Mild Steel \\
Connecting rod & Length $=120$ & Steel \\
& Bore $=24$ & Steel \\
Spring & Outer diameter $=36$ & \\
& Inner diameter $=30$ & Steel \\
\hline
\end{tabular}




\begin{tabular}{ccc}
\hline Driven gear & - No of teeth $=9$ & Mild steel \\
& - Type - spur gear & - length $=320 \mathrm{~mm}$ \\
U shaped shaft & - thickness $=20 \mathrm{~mm}$ & Steel \\
Straight shaft & - length $=200 \mathrm{~mm}$ & Steel \\
D. C generator & - diameter $=10 \mathrm{~mm}$ & \\
LED bulb & - Type - dynamo & - voltage $=12 \mathrm{v}$ \\
\hline
\end{tabular}

\section{Results and Discussion}

The results got from the design calculations are summarized in Table 4.

Table 4. Design Results

\begin{tabular}{cc}
\hline Component & Design Results \\
\hline \multirow{3}{*}{ Spring } & Spring rate $=1.7 \mathrm{~N} / \mathrm{mm}$ \\
& Number of turns $=14$ \\
& Torque $=10947.96 \mathrm{~N}-\mathrm{mm}$ \\
& Shear stress $=24787.83 \mathrm{~N} / \mathrm{mm}^{2}$ \\
Shaft & Deflection $=0.119 \mathrm{~mm}$ \\
& Torque $=146.4 \mathrm{~N}-\mathrm{mm}$ \\
& Shear stress $=0.0539 \mathrm{~N} / \mathrm{mm}^{2}$ \\
& Angle of contact $=20^{\circ}$ \\
Bearing & Reaction on bearing A $=9.47 \mathrm{~N}$ \\
& Reaction on bearing B $=2.73 \mathrm{~N}$ \\
& Life of bearing A \\
& $=4.96 \times 10^{6}$ revolutions \\
& Life of bearing B \\
& $=2.07 \times 10^{13}$ revolutions \\
Gear & Module $=3$ \\
& velocity ratio $=0.25$ \\
& Interference $=0.7$ \\
\hline
\end{tabular}

\subsection{Static Analysis of Spring and Footboard}

The static analysis of some of the components of the footstep power generating machine was done. The results got from the analysis of the necessary components are presented in tables and graphs.

\subsection{Spring Analysis Results}

The spring's physical properties, mechanical properties and force distributions in the $\mathrm{X}$, $\mathrm{Y}$ and $\mathrm{Z}$ co-ordinates are shown in Tables 5 and 6 respectively.

Table 5. Physical \& Mechanical Properties of Spring

\begin{tabular}{cc}
\hline Material & Steel \\
\hline Density & $7.85 \mathrm{~g} / \mathrm{cm}^{3}$ \\
Mass & $0.145351 \mathrm{~kg}$ \\
Area & $21,777.9 \mathrm{~mm}^{2}$ \\
Volume & $18,516 \mathrm{~mm}^{3}$ \\
Center of Gravity & $x=0.000223447 \mathrm{~mm}$ \\
Yield Strength & $y=135.002 \mathrm{~mm}$ \\
& $z=-0.29917 \mathrm{~mm}$ \\
\hline
\end{tabular}




\begin{tabular}{cc}
\hline Ultimate Tensile Strength & $345 \mathrm{MPa}$ \\
Young’s Modulus & $210 \mathrm{GPa}$ \\
Poisson's Ratio & 0.3 \\
Shear Modulus & $80.7692 \mathrm{GPa}$ \\
\hline & Table 6. Spring Force Values \\
\hline Load Type & $245.25 \mathrm{~N}$ \\
Magnitude & $22.628 \mathrm{~N}$ \\
Vector X & $-236.883 \mathrm{~N}$ \\
Vector Y & $59.348 \mathrm{~N}$ \\
Vector Z &
\end{tabular}

\subsubsection{Von Mises Stress}

The figure below shows the von Mises stress in different regions of the spring when a load of $100 \mathrm{~kg}$ is placed on the foot bar. The Von Mises stress of the spring is shown in Figure 4.

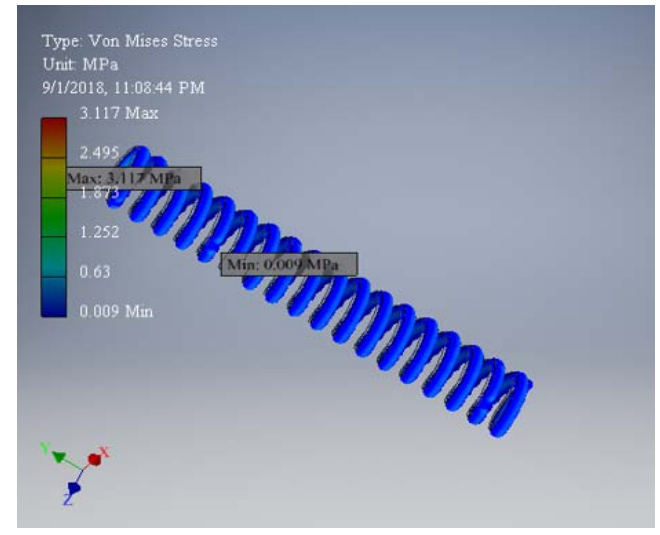

Figure 4. Von Mises Stress in the spring.

The Finite Element Analysis done using Autodesk Inventor software is summarized in Table 7.

Table 7. Spring Static Analysis Summary

\begin{tabular}{ccc}
\hline Name & Minimum & Maximum \\
\hline Volume & $18,516.3 \mathrm{~mm}^{3}$ & \\
Mass & $0.145353 \mathrm{~kg}$ & $3.11667 \mathrm{MPa}$ \\
Von Mises Stress & $0.00869094 \mathrm{MPa}$ & $1.86763 \mathrm{MPa}$ \\
$1^{\text {st }}$ Principal Stress & $-0.137906 \mathrm{MPa}$ & $0.150263 \mathrm{MPa}$ \\
$3^{\text {rd }}$ Principal Stress & $-1.73083 \mathrm{MPa}$ & $0.000273822 \mathrm{~mm}$ \\
Displacement & $0 \mathrm{~mm}$ & 15 \\
Safety Factor & 15 & $0.990931 \mathrm{MPa}$ \\
Stress XX & $-0.988447 \mathrm{MPa}$ & $0.287367 \mathrm{MPa}$ \\
Stress XY & $-1.73781 \mathrm{MPa}$ & $0.542401 \mathrm{MPa}$ \\
Stress XZ & $-0.528229 \mathrm{MPa}$ & $0.584505 \mathrm{MPa}$ \\
Stress YY & $-0.578698 \mathrm{MPa}$ & $0.412399 \mathrm{MPa}$ \\
Stress YZ & $-0.464399 \mathrm{MPa}$ & $0.988355 \mathrm{MPa}$ \\
Stress ZZ & $-0.969968 \mathrm{MPa}$ & $1.0238 \times 10^{-4} \mathrm{~mm}$ \\
X Displacement & $-1.0156 \times 10^{-4} \mathrm{~mm}$ & $6.8791 \times 10^{-6} \mathrm{~mm}$ \\
Y Displacement & $-2.7381 \times 10^{-3} \mathrm{~mm}$ & $7.8827 \times 10^{-5} \mathrm{~mm}$ \\
Z Displacement & $-7.842 \times 10^{-5} \mathrm{~mm}$ & $1.2863 \times 10^{-5}$ \\
Equiv. Strain & $3.6103 \times 10^{-8}$ &
\end{tabular}




\begin{tabular}{ccc}
\hline $1^{\text {st }}$ Principal Strain & $3.0676 \times 10^{-8}$ & $1.1330 \times 10^{-5}$ \\
$3^{\text {rd }}$ Principal Strain & $-1.0945 \times 10^{-5}$ & $-2.625 \times 10^{-8}$ \\
Strain XX & $-4.6810 \times 10^{-6}$ & $4.6484 \times 10^{-6}$ \\
Strain XY & $-1.0757 \times 10^{-5}$ & $1.7789 \times 10^{-6}$ \\
Strain XZ & $-3.2699 \times 10^{-6}$ & $3.3577 \times 10^{-6}$ \\
Strain YY & $-2.1195 \times 10^{-6}$ & $2.1411 \times 10^{-6}$ \\
Strain YZ & $-2.8748 \times 10^{-6}$ & $2.5529 \times 10^{-6}$ \\
Strain ZZ & $-4.5782 \times 10^{-6}$ & $4.6560 \times 10^{-6}$ \\
\hline
\end{tabular}

\subsubsection{Footboard Analysis}

The footboard's physical, mechanical properties and force distributions in the $\mathrm{X}, \mathrm{Y}$ and $\mathrm{Z}$ co-ordinates are listed in Tables 8 and 9 respectively.

Table 8. Physical \& Mechanical Properties of Footboard

\begin{tabular}{cc}
\hline Material & Steel, Mild \\
\hline Density & $7.85 \mathrm{~g} / \mathrm{cm}^{3}$ \\
Mass & $5.19984 \mathrm{~kg}$ \\
Area & $337,760 \mathrm{~mm}^{2}$ \\
& $662,400 \mathrm{~mm}^{3}$ \\
Center of Gravity & $x=230 \mathrm{~mm}$ \\
& $y=180 \mathrm{~mm}$ \\
Yield Strength & $z=-2 \mathrm{~mm}$ \\
Ultimate Tensile Strength & $207 \mathrm{MPa}$ \\
Young's Modulus & $345 \mathrm{MPa}$ \\
Poisson's Ratio & $220 \mathrm{GPa}$ \\
Shear Modulus & 0.275 \\
\hline Load Type & $86.2745 \mathrm{GPa}$ \\
\hline Magnitude & Table 9. Footboard Force Values \\
Vector X & $981.000 \mathrm{~N}$ \\
Vector Y & $0.000 \mathrm{~N}$ \\
Vector Z & $0.000 \mathrm{~N}$ \\
\hline
\end{tabular}

The Von Mises stress distribution over the footboard on application of $981 \mathrm{~N}$ force $(100 \mathrm{~kg})$ is shown in figure 5

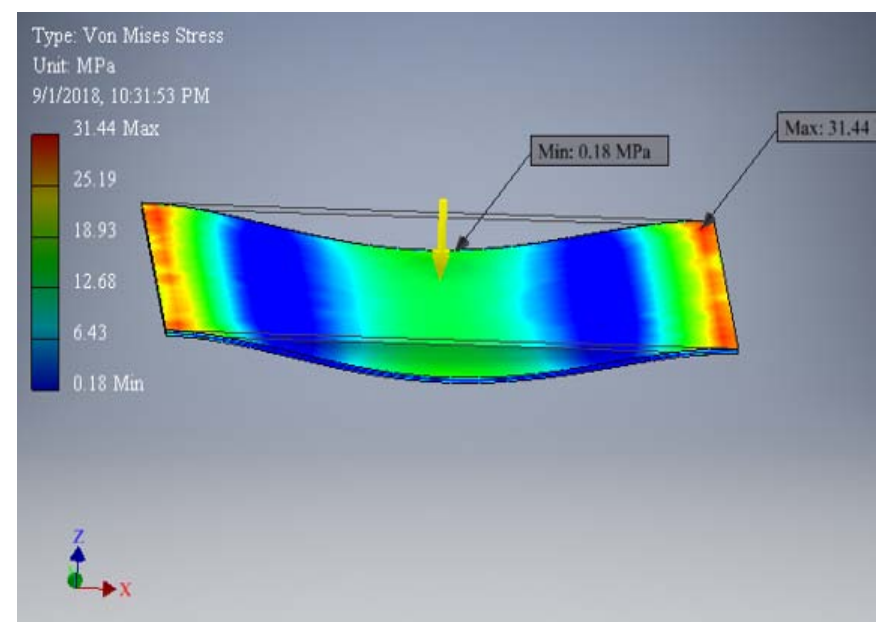

Figure 5. Von Misses Stress Distribution in Footboard. 
The corresponding displacement distribution is shown in Figure 6 .

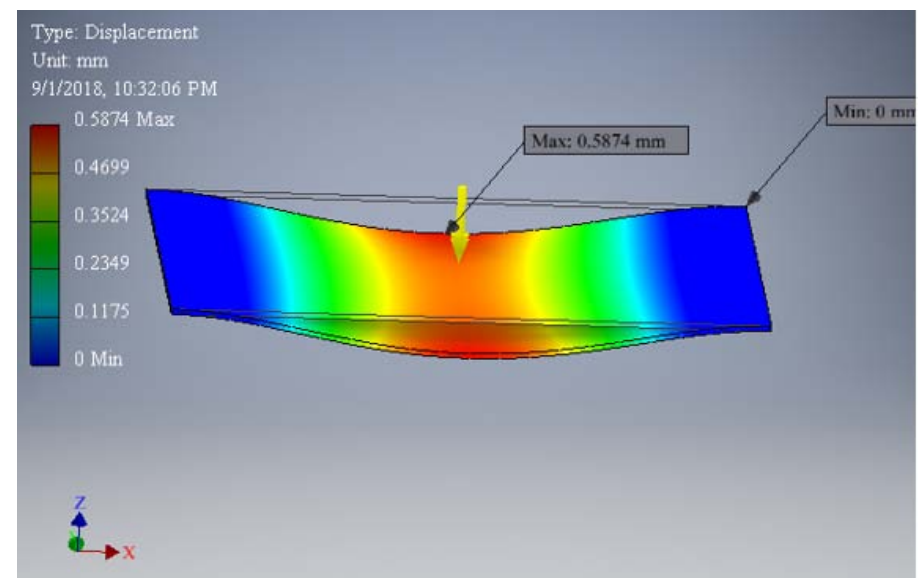

Figure 6. Footboard Factor of Safety.

The Finite Element Analysis is summarized in Table 10.

Table 10. Footboard Static Analysis Summary

\begin{tabular}{|c|c|c|}
\hline Name & Minimum & Maximum \\
\hline Volume & $662,400 \mathrm{~mm}^{3}$ & \\
\hline Mass & $5.19984 \mathrm{~kg}$ & \\
\hline Von Mises Stress & $0.176792 \mathrm{MPa}$ & $31.4377 \mathrm{MPa}$ \\
\hline $1^{\text {st }}$ Principal Stress & $-15.5508 \mathrm{MPa}$ & $40.3576 \mathrm{MPa}$ \\
\hline $3^{\text {rd }}$ Principal Stress & $-41.2078 \mathrm{MPa}$ & $15.2345 \mathrm{MPa}$ \\
\hline Displacement & $0 \mathrm{~mm}$ & $0.587365 \mathrm{~mm}$ \\
\hline Safety Factor & 6.585 & 15 \\
\hline Stress XX & $-41.1502 \mathrm{MPa}$ & $40.3042 \mathrm{MPa}$ \\
\hline Stress XY & $-2.75368 \mathrm{MPa}$ & $2.7746 \mathrm{MPa}$ \\
\hline Stress XZ & $-2.06052 \mathrm{MPa}$ & $1.95488 \mathrm{MPa}$ \\
\hline Stress YY & $-15.6087 \mathrm{MPa}$ & $15.2878 \mathrm{MPa}$ \\
\hline Stress YZ & $-0.997642 \mathrm{MPa}$ & $0.758438 \mathrm{MPa}$ \\
\hline Stress ZZ & $-15.6087 \mathrm{MPa}$ & $15.2878 \mathrm{MPa}$ \\
\hline X Displacement & $-7.9677 \times 10^{3} \mathrm{~mm}$ & $7.9663 \times 10^{3} \mathrm{~mm}$ \\
\hline Y Displacement & $-1.8009 \times 10^{-3} \mathrm{~mm}$ & $1.7989 \times 10^{-3} \mathrm{~mm}$ \\
\hline Z Displacement & $-0.587365 \mathrm{~mm}$ & $0 \mathrm{~mm}$ \\
\hline Equiv. Strain & $7.0808 \times 10^{-7}$ & $1.2864 \times 10^{-4}$ \\
\hline $1^{\text {st }}$ Principal Strain & $9.8645 \times 10^{-7}$ & $1.5024 \times 10^{-4}$ \\
\hline $3^{\text {rd }}$ Principal Strain & $-1.4953 \times 10^{-4}$ & $2.6521 \times 10^{-6}$ \\
\hline Strain XX & $-1.4914 \times 10^{-4}$ & $1.5024 \times 10^{-4}$ \\
\hline Strain XY & $-1.5959 \times 10^{-5}$ & $1.6080 \times 10^{-5}$ \\
\hline Strain XZ & $-1.1942 \times 10^{-5}$ & $1.1329 \times 10^{-5}$ \\
\hline Strain YY & $-2.5496 \times 10^{-5}$ & $2.4479 \times 10^{-5}$ \\
\hline Strain YZ & $-5.7818 \times 10^{-6}$ & $4.3955 \times 10^{-6}$ \\
\hline Strain ZZ & $-5.6327 \times 10^{-5}$ & $5.2795 \times 10^{-5}$ \\
\hline
\end{tabular}

The corresponding factor of safety distribution is shown in Figure 7. 


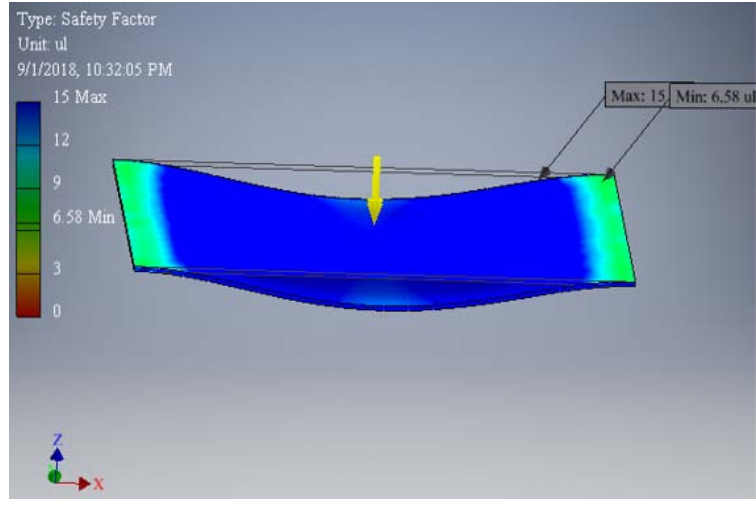

Figure 7. Footboard Factor of Safety.

\subsection{Experimentation and Evaluation}

In this section, a detailed evaluation of experimental test conducted on the manufactured footstep generator is presented. Based on the test results, a correlation was carried out to generate a predictive model for the prediction of voltage and power beyond experimental limits. The power input and output evaluations are presented in sections 4.3.1 and 4.3.2 respectively.

\subsubsection{Power Input}

Let us consider,

The average mass of human moving over the machine $=62 \mathrm{~kg}[8]$

The deflection caused by $62 \mathrm{~kg}=9 \mathrm{~cm}$

$$
\begin{gathered}
\text { Input power }=\text { workdone } / \text { time } \\
\text { Workdone }=\text { force } \times \text { distance } \\
\text { Force }=\text { mass }(\text { a }) \times \text { accl. due to gravity }(g) \\
\text { Force }=62 \times 9.81=608.22 \mathrm{~N}
\end{gathered}
$$

Hence,

$$
\begin{gathered}
\text { Workdone }=608.22 \times 0.09=54.73 \mathrm{Nm} \\
\text { Input power }=\frac{54.73}{60}=0.912 \text { watts }
\end{gathered}
$$

\subsubsection{Power Output}

$$
\begin{gathered}
\text { Power output }=\text { current }(I) \times \text { voltage }(V) \\
\text { But V }=\text { IR }(\text { Where } \mathrm{R}=\text { resistance })
\end{gathered}
$$

Therefore,

$$
\text { Power }=\frac{V^{2}}{R}
$$

The dynamo used has specification of $6 \mathrm{~V}, 3$ watts

$$
R=\frac{V^{2}}{P}=\frac{6^{2}}{3}=12 \Omega
$$

But the maximum voltage produced $=1.52 \mathrm{~V}$

Therefore,

$$
\begin{gathered}
\text { Power }=I V=\frac{V^{2}}{R}=\frac{1.52^{2}}{12}=0.193 \text { watts } \\
\text { Efficiency }=\frac{\text { Outpup power }}{\text { Input power }} \times 100 \%
\end{gathered}
$$




$$
\eta=\frac{0.913}{0.912} \times 100=21.162 \%
$$

The values of the corresponding load, voltage and power readings from the experiment are displayed in Table 11 and Figure 8 respectively.

Table 11. Corresponding Load, Voltage and Power Values

\begin{tabular}{ccc}
\hline Load $(\mathrm{kg})$ & Voltage $(\mathrm{V})$ & Power $(\mathrm{W})$ \\
\hline 50 & 0.5 & 0.021 \\
62 & 0.80 & 0.053 \\
75 & 1.52 & 0.193 \\
85 & 1.60 & 0.213 \\
100 & 1.60 & 0.213 \\
\hline
\end{tabular}

From Figure 8, an increase in load on the footstep power machine shows direct proportionality from $50 \mathrm{~kg}$ to $80 \mathrm{~kg}$ but differs beyond $80 \mathrm{~kg}$ as any increase in load shows no appreciable increase in neither voltage nor power. The above phenomena are attributed to the capacity of the installed alternator, since it cannot deliver beyond $1.6 \mathrm{v}$ or 0.22 watts. Figures 9 and 10 represent the curve fitting for the generated voltage and power out puts, where predictive models were generated to give an idea of the performance of the footstep machine beyond experimental boundaries. Figure 11 shows the interrelationship between voltage, power and efficiency and how they influence each other with significant level of 0.05 . The root mean square values for both voltage and power output greater than 0.9 shows a strong correlation.

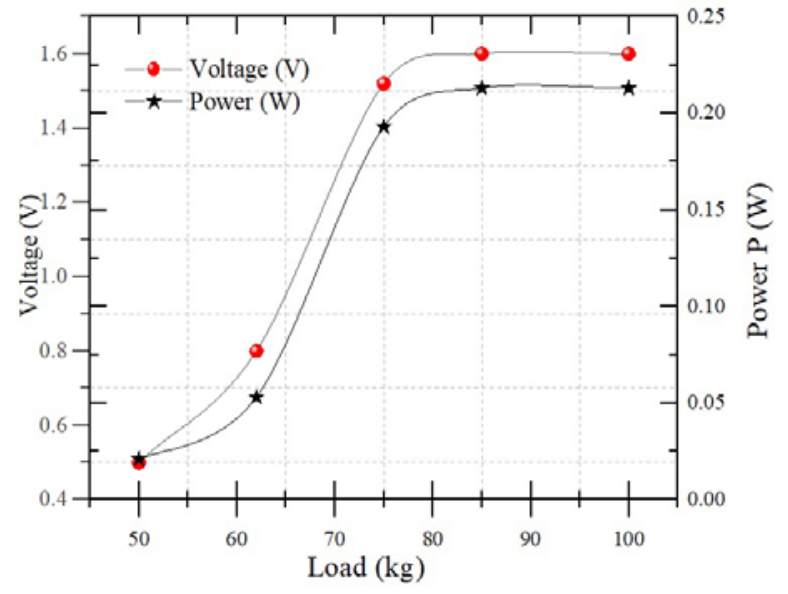

Figure 8. Experimental Results of Power and Voltage output due to applied load.

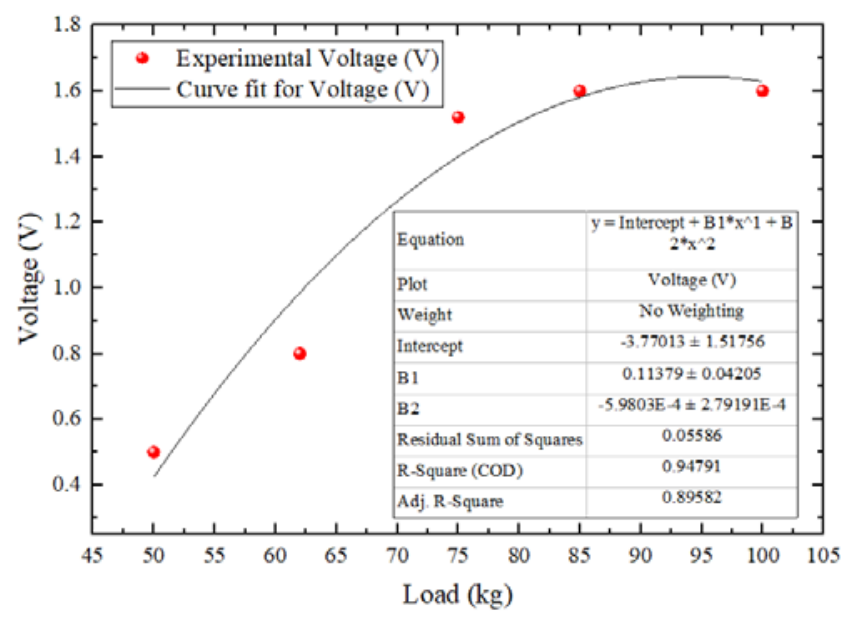

Figure 9. Curve fitting for Voltage output due to applied load. 


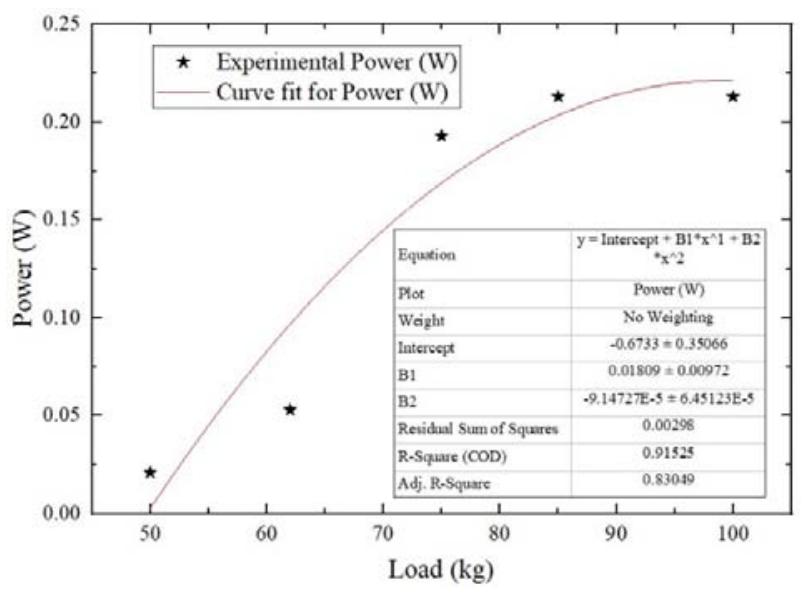

Figure 10. Curve fitting for Power Output due to applied load.

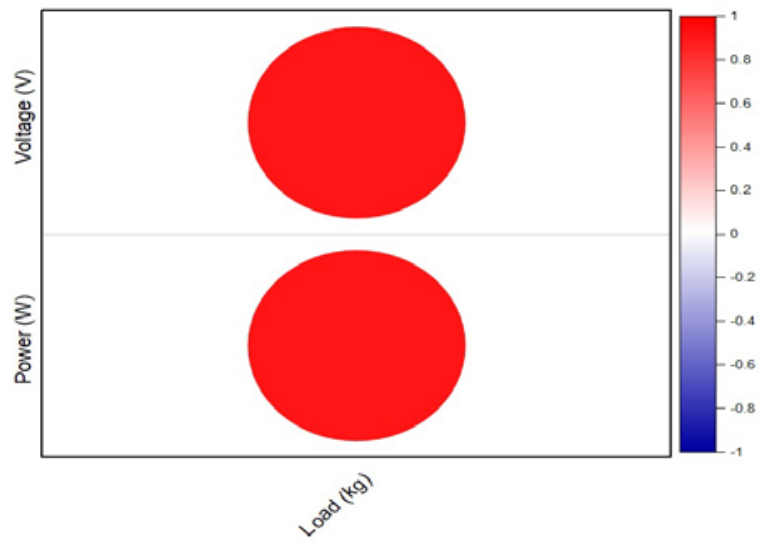

Figure 11. Curve fitting for Power Output due to applied load.

\section{Conclusion}

The static analysis of both the spring and footboard reveals that an increase in load results in an increase in the von Mises stress, displacement, 1st Principal stress, and $3^{\text {rd }}$ Principal stress of the material. Also, the factor of safety of the material was found to inversely proportional to load (see Figures 5, 6 and 7)

The yield strength and maximum stress of the footboard when a force of $981 \mathrm{~N}$ was applied were 207MPa and 40.3576MPa, respectively. The values above indicate the safety of the footboard material (mild steel) since the stress in the footboard is less than the yield strength of the material with corresponding factor of safety of 6.58445 .

As observed from Figure 7, points of maximum stress concentrations in the footboard are at the points where fixed constraints were applied to the board. The minimum stress in the footboard is at the point of application of the load. As shown in Figure 6, there was no displacement at the points on the footboard where the fixed constraints were applied, but this displacement increases from zero at the points of fixed constraints to a maximum value of 0.5874 at the point of application of the load which is the point of maximum displacement from the fixed ends.

Steel has a yield strength of 207MPa. The spring used in this design is made from steel, and the maximum stress concentration in the spring when acted on by a $245.250 \mathrm{~N}$ force as 3.11667MPa (that is the von Mises Stress). This is seen in Table 4. It is obvious that the material is in a safe zone. This is because the stress in the plate is less than the yield strength of the material.

In testing the setup, different weights were used on the prototype footstep power generating machine to get the output voltage using a multimeter. Table 11 shows the result of the experiments conducted on the prototype system. It was observed that the voltage and hence power readings kept changing with the change in the applied load, but this was discontinued from when a load of $85 \mathrm{~kg}$ was used, at this load value, the corresponding voltage and power values remained constant. This was because, at this point, the spring had attained its maximum vertical deflection. Moreso the capacity of the generator could be another contributing factor since it cannot generate power beyond its maximum capacity. Due to the above limitations, a correlation was carried out for predicting the voltage and corresponding power with both the $\mathrm{R}^{2}$-value greater than 0.9 , indicating a strong correlation. 


\section{References}

[1] O. A. Olugboji, I. Ohiemi, and C. Ajani. (2015). "Modelling and Design of an Auto Street Light Generation Speed Breaker Mechanism,” no. January, 2015, doi: 10.12691/ajme-3-3-3.

[2] S. Afzal. (2010). "Power generation,” Filtr. Sep., vol. 47, no. 6, p. 1, 2010, doi: 10.1016/S0015-1882(10)70267-6.

[3] “Electrical energy,” Nature, vol. 178, no. 4543. p. 1151, 1956, doi: 10.1038/1781151a0.

[4] J. Tour, K. Ashley. (2011). “construction of electric power generation using reverse electowetting,” 2011.

[5] K. Shiraishi, R. G. Shirley, and D. M. Kammen. (2018). "Geospatial multi-criteria analysis for identifying high priority clean energy investment opportunities: A case study on land-use conflict in Bangladesh,” Appl. Energy, vol. 235, no. August 2018, pp. 1457-1467, 2019, doi: 10.1016/j.apenergy.2018.10.123.

[6] O. A. Olugboji and C. Ajani. (2019). “Development of a speed breaker mechanism for generating,” no. February, 2019.

[7] S. p. Kari, M., Ahsan, K., Shag, H., Kibul, H. (2016). “Electrical power generation through speed breaker,” 9th Int. Conf. Electron. Comput. Eng., 2016.

[8] M. Brooke. (2009). “The weight of the world,” Sight and Sound, 2009.

[9] M. Design, Khurmi, R. S., and J. K. Gupta. (2019). A textbook of machine design. S. Chand publishing, 2005.2019.

[10] Richard G. Budynas and J. Keith Nisbett. (2015). Shigley’s Mechanical Engineering Design. Tenth edit. New York: McGraw-Hill Education, 2 Penn Plaza, New York, NY 10121., 2015.

[11] “Unconfirmed 287199.crdownload.”

[12] H. Patel, H. K. Patel, S. K. Dutta, P. Sahu, and K. Das. (2015). "Production of Electricity by the Method of Road Power Generation,” Int. J. Res., vol. 2, no. 5, pp. 636-640, 2015, [Online]. Available: http://edupediapublications.org/journals/index. php/ijr/article/view/2030.

[13] I. Mahmud. (2018). “Electrical Power Generation Using Footsteps,” Eur. Sci. Journal, ESJ, vol. 14, no. 21, p. 318, 2018, doi: 10.19044/esj.2018.v14n21p318.

[14] A. L. Gorle, A. V. Thawale, and L. H. Patil. (2018). “'Literature Review on Electricity Generation using Speed Breaker,”” Ijarcce, vol. 7, no. 10, pp. 44-47, 2018, doi: 10.17148/ijarcce.2018.71010.

[15] B. S. Sarma, V. Jyothi, and D. Sudhir. (2014). “Design of Power Generation Unit Using Roller Mechanism,” IOSR J. Electr. Electron. Eng., vol. 9, no. 3, pp. 55-60, 2014, doi: 10.9790/1676-09315560.

[16] B. Swetha, L. Prasanna, N. T. Anjum, and R. Chandra. (2020). “Footstep Power Generation System,” Int. J. Mod. Trends Sci. Technol., vol. 6, no. 5, pp. 100-104, 2020, doi: 10.46501/ijmtst060517.

[17] A. Kumar, A. Kumar, D. Arockiaraj, and G. P. U.S. (2018). “Energy Harvesting Using Rack and Pinion Mechanism,” J. Mech. Civ. Eng., vol. 15, no. I, pp. 75-80, 2018, doi: 10.9790/1684-1501047580.

[18] G. Vamsi Krishna, S. Srinivasa Rao, P. Sriharsha, B. V. Neerav, and G. E. N. M. S. Satyasai. (2019). "Modeling and analysis of flat spiral spring based speed breaker device for generation of electricity,” Int. J. Recent Technol. Eng., vol. 8, no. 1, pp. 555-561, 2019.

[19] A. Mishra, et al. (2013). “Electricity Generation from Speed Breakers,” Int. J. Electr. Electron. Res. ISSN, vol. 4, no. 1, pp. 25-27, 2013, [Online]. Available: www.theijes.com.

[20] M. M. Durai. (2017). “Using Road Speed Breakers to Extract Electric Power,” Int. J. Adv. Res. Basic Eng. Sci. Technol., vol. 3, no. 24, pp. 464-470, 2017.

[21] J. E. Dara, C. M. Odazie, P. C. Okolie, and A. O. Azaka. (2020). "Design and construction of a double actuated mechanical speed breaker electricity generator,” Heliyon, vol. 6, no. 9, p. e04802, 2020, doi: 10.1016/j.heliyon.2020.e04802.

[22] K. Kolhe and A. Pandhare. (2017). "International Journal of Current Engineering and Technology Electric Power Generation System from Speed Breaker by using Rack and Pinion Mechanism,” 1151| Int. J. Curr. Eng. Technol., vol. 7, no. 3, pp. 1151-1158, 2017, [Online]. Available: http://inpressco.com/category/ijcet.

[23] M. Palanivendhan, S. Logeshwaran, G. Naresh, K. Ankush, A. Sidhaant, and S. Shivam. (2020). "Design and fabrication of speed bump for energy generation,” IOP Conf. Ser. Mater. Sci. Eng., vol. 993, no. 1, 2020, doi: 10.1088/1757-899X/993/1/012149.

[24] K. C. A. O. A. Olugboji, M. S. Abolarin, I. E. Ohiemi. (2016). "Development of a Speed Breaker Mechanism for Generating,” Proc. 2016 Annu. Conf. Sch. Eng. Eng. Technol., no. February, pp. 131-138, 2016.

[25] A. K. Singh. (2021). “Electricity Generation Through Speed Breaker Mechanism,” Strad Res., vol. 8, no. 5, 2021, doi: 10.37896/sr8.5/025.

[26] T. Krupenkin and J. A. Taylor. (2011). "Reverse electrowetting as a new approach to high-power energy harvesting,” Nat. Commun., vol. 2, no. 1, pp. 1-8, 2011, doi: 10.1038/ncomms1454. 
[27] P. Bhagdikar, S. Gupta, N. Rana, R. Jegadeeshwaran, and B. Sciences. (2014). "G Eneration of E Lectricity With the Use of S Peed,” 2017 IEEE Int. Conf. Power, Control. Signals Instrum. Eng., vol. 7, no. 2, pp. 589-595, 2014.

[28] J. D. Jaymin. (2015). “Power Generation from Speed Breakers by Air Compression Method,” Int. J. Eng. Dev. Res., vol. 3, no. 2, pp. 75-80, 2015.

[29] J. Khurmi, R., Gupta, “machine design,” in international edition.

[30] H. Yang, S. Hong, B. Koo, D. Lee, and Y. B. Kim. (2017). "High-performance reverse electrowetting energy harvesting using atomic-layer-deposited dielectric film,” Nano Energy, vol. 31, pp. 450-455, 2017, doi: 10.1016/j.nanoen.2016.11.006.

[31] K. M. Ullah, K. M. Ahsan-Uz-zaman, S. Hosen, R. H. Khan, and S. Parvin. (2017). "Electrical power generation through speed breaker,” Proc. 9th Int. Conf. Electr. Comput. Eng. ICECE 2016, pp. 30-33, 2017, doi: 10.1109/ICECE.2016.7853848.

[32] T. H. Hsu, S. Manakasettharn, J. A. Taylor, and T. Krupenkin. (2015). "Bubbler: A Novel Ultra-High Power Density Energy Harvesting Method Based on Reverse Electrowetting,” Sci. Rep., vol. 5, pp. 1-13, 2015, doi: 10.1038/srep16537.

[33] S. M. Mahind. (2016). “Power Generation Through Foot Step,” Int. Eng. Res. J., vol. 2, no. 3, pp. 1009-1012, 2016.

[34] Anonymous. “Shaft (mechanical engineering.” https://en.m.wikipedia.org/wiki/Shaft_(mechanical_engineering) (accessed Aug. $25,2018)$.

[35] Anonymous. “Ball Bearing.” https://en.m.wikipedia.org/wiki/Ball_bearing (accessed Jul. 25, 2018).

[36] Ametek. (2015). "What are the common spring materials (springs),” 2015. http://www.hunterspringandrell.com/support/faq/ what-are-the-common-spring-materials-springs (accessed Aug. 29, 2018).

[37] J. Richard, G., Nisbett. (2011). “No Title,” in mechanical engineering design, Ninth edit., 2011.

[38] F. Nwachinemelu and C. Anyaegbunam. (2016). "Power Generation from a Renewable Energy Source - Speed Breaker Generators,” no. June, pp. 1-5, 2016.

[39] N. Kachale. (2019). “Road Power Generation,” Int. J. Res. Appl. Sci. Eng. Technol., vol. 7, no. 5, pp. 2761-2766, 2019, doi: 10.22214/ijraset.2019.5455.

[40] T. A. T. Aziz and M. S. Subri. (2019). “Footstep power generation using Arduino Uno,” AIP Conf. Proc., vol. 2129, no. July, 2019, doi: 10.1063/1.5118105.

[41] K. F. S. F. R. M. El Habrouk. (2019). “Speed Breaker Energy Harvester Using Roller Mechanism,” Int. J. Sci. Res., vol. 8, no. 1, pp. 598-605, 2019, [Online]. Available: https://www.ijsr.net/archive/v8i1/ART20194214.pdf.

[42] C. K. Ang, A. A. Al-Talib, S. M. Tai, and W. H. Lim. (2019). "Development of a footstep power generator in converting kinetic energy to electricity,” E3S Web Conf., vol. 80, pp. 10-13, 2019, doi: 10.1051/e3sconf/20198002001.

[43] G. Dhanalakshmi, T. Manjulai, M. Mirunalini, and S. Sangeetha Mary. (2017). “Footstep Power Generation System,” Int. J. Eng. Comput. Sci., 2017, doi: 10.18535/ijecs/v6i4.38.

[44] A. S. Fawade. (2015). "Air Compression and Electricity Generation by Using Speed Breaker with Rack And Pinion Mechanism,” Www.Ijmer.Com, vol. 5, pp. 23-28, 2015.

[45] A. A. Al Ahmadi, et al. (2018). "Power generation through road speed breakers-An experimental approach,” 2018 Adv. Sci. Eng. Technol. Int. Conf. ASET 2018, pp. 1-6, 2018, doi: 10.1109/ICASET.2018.8376796.

[46] M. S. Aljohani. (2020). “Mechanical Footstep power generator,” 2020. 